\title{
Thoughts on Directed Verdicts and Summary Judgments
}

\author{
David P. Currie†
}

Directed verdicts and summary judgments are two useful tools of modern civil procedure for truncating the normal trial procedure in jury cases. Both are surrounded by unnecessary confusion and the relationship between the two seems poorly understood. My aim is to clarify, simplify, and improve them.

\section{DiRECTEd Verdicts}

In "actions at common law," issues of historical fact, and some applications of law to fact (for example, negligence) are ordinarily left to jury decision upon request of either party. This practice represents in part a conviction that on such matters the judge's legal training gives him no special competence and that the collective judgment of persons relatively representative of the community is preferable. Yet we do not allow the jury complete freedom even on these issues, and for good reason. To permit a jury to find the facts contrary to overwhelming evidence, or upon wholly insufficient evidence, would license juries to undermine the law.

Thus, modern practice permits the judge to direct a verdict, or to enter a judgment notwithstanding the verdict, if on the evidence presented "there can be but one conclusion ... that reasonable men could have reached."' On its face this standard appears highly subjective but straightforward: the judge is not to substitute his judgment for that of the jury; he is not to intervene except in extreme cases; but he is to see to it that the jury does not abuse its power. For example, one might think that the rule stated above would not permit a jury to find a traffic light green if forty bishops testified it was not, or a debt unpaid in the face of a signed receipt without evidence of fraud or the like. But the familiar textbook case of Simblest v. Maynard ${ }^{2}$ shows that the rule is by no means as simple as it appears.

Simblest referred to three divergent tests for determining whether a jury could reasonably find for the party against whom the

† Harry N. Wyatt Professor of Law, The University of Chicago.

1 Simblest v. Maynard, 427 F.2d 1 (2d Cir. 1970).

${ }^{2}$ Id. 
motion for a directed verdict is made. The judge may consider: 1) all the evidence; 2 ) only the evidence favorable to the party moved against; or 3) both the evidence favorable to the party moved against and the evidence favoring the moving party that is uncontradicted and unimpeached. On the second test, taken literally, a jury would be allowed to disbelieve the unopposed testimony of forty bishops and to ignore the unimpeached receipt. Under the third standard, the contrary testimony of the adverse party would preclude a directed verdict in the same cases. Indeed, if the trial judge must always disregard evidence favoring the moving party, he may never direct a verdict for the party with the burden of proof on the issue unless the facts are admitted. And some courts have so held. ${ }^{3}$ It is, to put it gently, difficult to reconcile such results either with the rule that juries may not act unreasonably or with the underlying policy of preventing juries from undermining the law.

Often cited ${ }^{4}$ as authority for looking only to the evidence favoring the party moved against is the Supreme Court's opinion in Wilkerson $v$. McCarthy, ${ }^{5}$ which flatly says that this is the "established rule." No citations or reasons accompany this statement. Just a few years before, the Court had explicitly considered evidence favoring the moving party in Pennsylvania Railroad $v$. Chamberlain. ${ }^{6}$ And the statement in Wilkerson was quite unnecessary to the result. On the disputed factual question whether employees customarily walked across a narrow board over a pit, there was testimony of approximately equal weight on each side; on any test, a jury could reasonably have found either way.

One possible explanation of the Wilkerson dictum lies in the fact that Wilkerson was an action under the Federal Employers Liability Act. ${ }^{7}$ Supreme Court pronouncements on the jury's role in such cases have sometimes been distinguished on the thinly disguised ground that the Court allows the jury in an F.E.L.A. case to nullify a negligence requirement with which it has no sympathy. ${ }^{8} \mathrm{As}$ Judge Rives has said, however, ${ }^{9}$ there is nothing either in the Act or in the Supreme Court decisions interpreting it to suggest that a

${ }^{3}$ See Sunderland, Directing a Verdict for the Party Having the Burden of Proof, $11 \mathrm{Mrch}$.

L. Rev. 198 (1913), and cases cited.

'See, e.g., Simblest v. Maynard, 427 F.2d 1, 5 (2d Cir. 1970).

s 336 U.S. 53, 57 (1949).

- 288 U.S. 333 (1933).

745 U.S.C. $\$ \S 51-60$ (1970).

" E.g., Boeing Co. v. Shipman, 411 F.2d 365, 370-73 (5th Cir. 1969) (F.E.L.A. requires only "slight negligence," which played "any part" in harming the employee).

' Id. at 384-92 (concurring in part and dissenting in part). 
special standard should apply. Indeed, there is some question whether the seventh amendment permits a less exacting degree of judicial supervision in some cases than in others. Justice Frankfurter has argued that appropriate judicial control is one aspect of the jury trial guaranteed by the Constitution. ${ }^{10}$ In any event, the policy of jury nullification is antithetical to the policy assumptions on which the reasonable juror standard is based and logically calls for abandonment of all judicial control over juries. If this is the reason for limiting the evidence a judge may consider in passing on a motion for a directed verdict, the Wilkerson test is an arbitrary halfway measure.

But despite Wilkerson's departure from recent Supreme Court practice, the test it announced was clearly not an unprecedented F.E.L.A. innovation. The Court utilized a similar test as long ago as 1837, in Ewing $v$. Burnet, $"$ and it gave a reason for doing so. The action was for ejectment. The defendant asserted adverse possession, and the plaintiff countered that the defendant had prior notice of his title. The denial of the plaintiff's request for a peremptory instruction was affirmed. The Court reasoned that because credibility was a matter for the jury, the judge must assume in ruling on the motion that the plaintiff's witnesses were lying and the defendant's were not; although there was nothing to contradict the plaintiff's evidence of notice, the jury might disbelieve it. ${ }^{12}$ This explanation would limit the Wilkerson rule to cases in which the evidence to be ignored is testimonial, for there is no question of the credibility of a written receipt, although, as Professor Sutherland has pointed out, ${ }^{13}$ the authenticity of such a document may itself depend upon oral testimony. But the South Dakota Supreme Court's answer to this position, quoted favorably by Wigmore,$^{14}$ seems compelling: "A jury has no greater or better right to act arbitrarily or unreasonably in forming a judgment or opinion as to whether or not a witness speaks the truth than it has to act unreasonably in arriving at any other opinion or conclusion."15

10 Wilkerson v. McCarthy, 336 U.S. at 64-65 (concurring opinion).

" 36 U.S. (11 Pet.) 41 (1837).

${ }^{12} I d$. at 51 . Judge Learned Hand argued that this position was logically sound but ruled that its adoption would unduly constrict judicial control of juries. Pariso v. Towse, 45 F.2d 962, 964 (2d Cir. 1930).

is Sunderland, supra note 3 , at 206.

" 9 J. Wigmore, Evidence $§ 2405$ (3d ed. 1940) (citing Jerke v. Delmont State Bank, 54 S.D. 446, 223 N.W. 585 (1929)).

${ }^{15}$ Jerke v. Delmont State Bank, 54 S.D. 446, 459-60, 223 N.W. 585, 590-91 (1929). It is true that an appellate court is in no position to review a trial judge's evaluation of witness demeanor, but that does not seem to me to justify giving the jury power to act unreasonably. 
Thus if we begin with the premise that the directed verdict is a device to keep juries from acting unreasonably, any limitations on what evidence the judge may consider appear highly artificial. However, the dissenting opinion of Mr. Justice Black in Galloway $v$. United States ${ }^{16}$ suggests that the premise itself may be historically and thus constitutionally unsound. When the seventh amendment was adopted, according to Justice Black, there were but two vehicles for interfering with the jury on account of insufficient evidence: the motion for new trial and the demurrer to the evidence. Any substantial expansion of judge control beyond these precedents would in his view contravene the amendment. ${ }^{17}$ Galloway was not specifically concerned with the question whether the judge may look at all the evidence, but the Black principle has important implications for that issue. The new trial practice cannot justify the direction of a verdict, which has the far more severe consequence of terminating the case on the merits. The demurrer to the evidence did result in a final judgment, but to make it a defendant waived his right to offer evidence and admitted the facts the plaintiff's evidence tended to prove..$^{18}$ If the modern directed verdict cannot differ substantially from this precedent, it follows that the judge must disregard any evidence-even documentary-introduced by the moving party. This test differs slightly from that of Wilkerson, which focuses not upon who introduced the evidence but upon whom it favors; but it is very close.

The majority decision in Galloway, however, decisively rejected the thesis that the boundaries of the obsolete demurrer to the evidence confine the directed verdict of today. ${ }^{19}$ Eighteenth-century practice essentially forbade a jury to act upon speculation as a substitute for proof. The Court reasoned that the amendment did not freeze the details of that practice; in particular, it did not require the Court to follow 1791 precedents in determining whether "any evidence" rather than "substantial evidence" of a disputed fact was sufficient to put the issue to the jury. This reasoning seems to justify a departure from the old rule that on demurrer to the evidence only the evidence of the party moved against is considered. Indeed the Court suggested as much in dictum: "It may be doubted that the Amendment requires challenge to an opponent's case to be made without reference to the merits of one's own and at the price of all

\footnotetext{
18 319 U.S. 372 (1943).

${ }^{17}$ Id. at 396-407 (Black, J., dissenting).

is See F. James \& G. Hazard, Civil Procedure 234 (2d ed. 1977).

11 319 U.S. at 388-95.
} 
opportunity to have it considered." ${ }^{20}$ Galloway opens the door to a rational system of jury supervision based upon the policy of keeping juries from acting unreasonably. This sound policy has the sanction of Supreme Court cases prior to Wilkerson, and the contrary conclusion in that opinion was mere dictum. I therefore urge that in passing upon motions for directed verdict or judgment notwithstanding the verdict federal judges consider all the evidence, ${ }^{21}$ and that rule $50(a)^{22}$ be amended to make this clear.

\section{SUMmary JUdGMENTS}

Under Federal Rule of Civil Procedure 56(c) summary judgment may be granted, without trial, on the basis of affidavits, depositions, and other materials showing "that there is no genuine issue as to any material fact and that the moving party is entitled to relief as a matter of law."23 The purpose of the summary judgment device is to ascertain whether the parties have evidence justifying the burden of a trial. ${ }^{24}$

In Adickes v. S.H. Kress Co. ${ }^{25}$ the Supreme Court reversed a summary judgment for the defendant because the materials supporting the motion failed to disprove an alleged conspiracy to deny civil rights. The Court strongly suggested in dictum that an uncontroverted affidavit denying the conspiracy allegations would have required the opposite result. The holding confines the summary judgment procedure so narrowly as to impair its effectiveness, while the dictum expands it far enough to threaten the right to jury trial.

The dictum finds nominal support in the 1963 amendment to rule $56(\mathrm{e})$ that the party against whom summary judgment is sought "may not rest upon the mere allegations or denials of his pleading" but must "set forth the specific facts showing that there is a genuine issue for trial." ${ }^{26}$ But if a jury would be free to disbelieve an uncontradicted witness at trial, as is sometimes the case, ${ }^{27}$ to grant summary judgment for a party having the burden of proof on the basis

${ }^{20}$ Id. at 392.

21 I do not mean to resolve here the question whether state or federal law governs this issue in diversity cases. See, e.g., Boeing Co. v. Shipman, 411 F.2d 365 (5th Cir. 1969).

22 FED. R. Civ. P. 50(a).

23 FED. R. Civ. P. 56(c).

24 See F. James \& G. Hazard, Civil Procedure 219-21 (2d ed. 1977); Corwin v. Los Angeles Newspaper Serv. Bureau Inc., 4 Cal. 3d 842, 851, 94 Cal. Rptr. 785, 790, 484 P.2d 953, 958 (1971).

${ }^{25} 398$ U.S. 144 (1970).

${ }^{28}$ FED. R. Civ. P. 56(e).

27 E.g., Ferdinand v. Agricultural Ins. Co., 22 N.J. 482, 126 A.2d 323 (1956); see Bobbe, The Uncontradicted Testimony of an Interested Witness, 20 CoRNell L.Q. 33 (1934). 
of an affidavit embodying such a witness's testimony would infringe the right to jury trial guaranteed by the seventh amendment, ${ }^{28}$ the Rules Enabling Act, ${ }^{29}$ and federal rules themselves. ${ }^{30}$ Rule 56(e) does not require such a result; by its terms, the consequence of a failure to file counter-affidavits is that summary judgment shall be granted "if appropriate." 31 The holding of Adickes itself makes clear that summary judgment is to be denied even in the absence of a response unless the moving party's showing is adequate in itself to justify the relief sought. "[1]f appropriate" means if the test for summary judgment is met, that is, if the materials on file show that the moving party is entitled to relief.

This conclusion is confirmed by the notes of the Advisory Committee. The 1963 amendment was designed to reverse a line of decisions refusing summary judgment, in the face of a strong evidentiary showing, simply on the basis of contrary allegations in the pleadings. The Committee emphasized that the amendment was not meant to dispense with the need for such a showing: "Where the evidentiary matter in support of the motion does not establish the absence of a genuine issue, summary judgment must be denied even if no opposing evidentiary matter is presented." 32 Indeed the Committee expressly addressed the issue of credibility: when a material issue "cannot be resolved without observation of the demeanor of witnesses in order to evaluate their credibility, summary judgment is not appropriate." ${ }^{33}$ Thus rule 56 as well as the enabling statute and the Constitution forbids the entry of summary judgment unless the evidence before the court would justify a directed verdict if presented at trial. To the extent the Adickes dictum suggests the contrary, it should not be followed.

The actual holding of Adickes, however, leans too far in the opposite direction. The defendant's crucial omission, according to the Court, was its failure to deny that a policeman had been in the store; if a policeman had been present, a jury might reasonably have inferred that he had conspired with the clerk to refuse the plaintiff

29 U.S. ConST. amend. VII provides: "In suits at common law, where the value in controversy shall exceed twenty dollars, the right of trial by jury shall be preserved . . . "

228 U.S.C. $\$ 2072$ (1970) provides: "Such rules . . . shall preserve the right of trial by jury as at common law and as declared by the Seventh Amendment to the Constitution."

${ }^{30}$ FED. R. CIv. P. 38(a) provides: "The right of trial by jury as declared by the Seventh Amendment to the Constitution or as given by a statute of the United States shall be preserved to the parties inviolate."

"FED. R. Crv. P. 56(e).

${ }^{32}$ FED. R. Civ. P. 56(e), Advisory Committee Notes (1963), 31 F.R.D. 648 (1963).

${ }^{3}$ Id. 
service. ${ }^{34}$ The inference itself appears strained enough, but the striking fact is that there was no evidence before the Court suggesting a policeman was in the store. At trial the plaintiff would have had the burden of production and persuasion on the conspiracy issue, so on the record she would have suffered a directed verdict. Yet summary judgment was held improper because, in contrast to the situation at trial, the burden was on the defendant to show the absence of a genuine issue of fact. Some courts and commentators have carried this idea to the extreme of treating the moving party in such a case as though he were being required to discharge the burden of production or even persuasion at trial. ${ }^{35}$

This reasoning is based on the ambiguous requirement of rule 56(c) that the materials on file "show . . . that the moving party is entitled to a judgment" 36 and the statement of the Advisory Committee that the movant's evidentiary materials must "establish the absence of a genuine issue." This statement does indeed suggest that even a party with the burden of proof may avoid a summary judgment without producing any evidence unless his opponent makes a strong evidentiary showing. This conclusion, however, undermines the purpose of the rule, which is to discover whether the parties have enough evidence to justify the time and expense of a trial. Professor Louis, while criticizing the more extreme manifestations of the movant's burden on this ground, insists that the moving party, if he would not have the burden of proof at trial, make a showing that would justify a jury verdict in his favor if he had: anything less would allow harassment of the opposing party ${ }^{37}$ This fear seems unfounded, for discovery can require far more burdensome disclosure, and the evidence must in any event be prepared for trial. Thus the Adickes dictum that an uncontradicted affidavit asserting the policeman's absence would have justified summary judgment seems correct in policy but not, as the Court intimated, because such an affidavit would have foreclosed a jury finding that a policeman was in the store. Rather, although a jury might have been entitled to disbelieve the arguably interested testimony of a policeman or of a store employee, its doing so would nevertheless have left the plaintiff subject to a directed verdict for failure to satisfy her burden of proof. ${ }^{38}$

398 U.S. at 158.

${ }^{35}$ See authorities cited in Louis, Federal Summary Judgment Doctrine: A Critical Analysis, 83 YALE L.J. 745, 752 (1974).

${ }^{38}$ FED. R. Civ. P. 56(c).

${ }^{37}$ Louis, supra note 35 at 749-50.

${ }^{3 x}$ Cases following the rule that disbelief of testimony will not serve as proof of facts 
The purpose of rule 56 requires that summary judgment be granted if and only if the evidence before the court would justify a directed verdict if presented at trial.$^{39}$ Consequently, the rule should be amended to make clear that a motion for summary judgment, without more, puts an opposing party with the burden of proof to the task of producing evidence sufficient to sustain a favorable verdict.

contrary to that testimony are collected in J. Maguire, J. Weinstein, J. Chadbourn \& J. Mansfield, Cases and Materials on Evidence $998-99$ (6th ed. 1973).

3. That the judge has not yet seen the demeanor of the witnesses should make him more hesitant to enter summary judgement than to direct a verdict whenever there is any chance that demeanor might detract from the compelling nature of the written evidence. 